\title{
LAJU ADSORPSI DAN DESORPSI PARAQUAT PADA TANAH PERTANIAN DESA OESAO KECAMATAN KUPANG TIMUR
}

\author{
Sherlly M.F. Ledoh, Hermania Em Wogo, Siti Arianti S.A \\ Jurusan Kimia, Fakultas Sain dan Teknik \\ Universitas Nusa Cendana, Kupang-NTT
}

\begin{abstract}
The research about determination of kinetic adsorption and desorption rate of paraquat on agriculture area Oesao-east Kupang has been done. The aim of this research was to determine the kinetic of paraquat adsorption before and after saturated and to model the desorption. The research consisted of evaluation of the analitycal procedure for paraquat, pattern of soil kinetic adsorption and paraquat desorption. The result of procedure evaluation showed that reduced paraquat absorbed at $\lambda$ maximum $606 \mathrm{~nm}$ and relative stability at 0-150 minutes. Constant of paraquat kinetic adsorption at natural state bigger than saturated state. $\mathrm{k}_{1}$ value at natural state was 0,011 per minute whereas $\mathrm{k}_{1}$ value at saturated state was 0,003 per minute. Desorption model of paraquat by using three desorbents were ammonium chloride, 29,2\% of sea water salinity and aquadest showed the best desorbent was ammonium chloride, followed by sea water and aquadest.
\end{abstract}

Keywords : adsorption, desorption, paraquat

\section{PENDAHULUAN}

Herbisida merupakan salah satu jenis pestisida yang digunakan untuk mengendalikan dan membunuh gulma. Terdapat dua tipe herbisida menurut aplikasinya: herbisida pra-tumbuh (pre emergence herbicide) dan herbisida pasca-tumbuh (post emergence herbicide). Herbisida pra-tumbuh (pre emergence herbicide), bersifat non selektif, yang berarti membunuh semua tumbuhan yang ada termasuk tumbuhan pokoknya. Herbisida pasca-tumbuh (post emergence herbicide), bersifat selektif, dalam arti tidak mengganggu tumbuhan pokoknya.

Gramoxon adalah salah satu jenis herbisida yang banyak digunakan di lahan pertanian. Bahan aktif gramoxon yaitu paraquat (1,1-dimetil-4,4bipiridilium). Paraquat merupakan herbisida golongan amonium kuartener yang merupakan herbisida kontak (Sudarmo, 1988) dan bersifat tidak selektif (Bangun dan Pane, 1984).
Penggunaan paraquat secara terus menerus dapat merusak lingkungan dan mengganggu ekosistem tanah oleh karena keberadaan residunya di tanah. Menurut Sastroutomo (1992), jenis herbisida paraquat terikat kuat oleh butir-butir tanah yang menyebabkan senyawa ini dapat bertahan lama di dalam tanah dan tidak dapat diserap oleh akar sehingga efektivitasnya dalam mengendalikan gulma menjadi berkurang.

Adsorpsi dan desorpsi herbisida oleh permukaan padatan tanah diketahui sebagai proses penting yang mampu mempengaruhi perilaku herbisida di dalam tanah dan air tanah. Ketika senyawa paraquat kontak dengan tanah, baik karena aplikasi, terjatuh atau tertumpah, atau karena terbawa oleh air hujan atau air irigasi, sebagian akan tahan dan tinggal dalam tanah melalui proses adsorpsi, sebagian lagi akan berada di dalam air diantara partikel-pertikel tanah (Kopytko dkk., 2002).

Pada penelitian tanah asam Kalimantan, (de Rozari, 2003) hasil 
konstanta laju adsorpsi pada tanah setelah dijenuhkan lebih besar dari keadaan natural. Hal ini mengindikasikan bahwa pada proses leaching yang dilakukan diikuti dengan terikatnya ion amonium pada situs aktif permukaan padatan tanah yang bermuatan negatif. Pada proses ini tidak semua paraquat yang ada pada adsorben tanah tergantikan oleh ion amonium. Hal ini juga mempengaruhi proses desorpsi pada penentuan tersebut, di mana pada tanah asam ini terdapat mineral kaolinit, montmorilonit dan bahan organik yang situs-situs aktifnya sebagian besar bermuatan negatif maka hanya kation 1,1-dimetil-4,4-bipiridilium yang teradsorpsi pada permukaan luar dan yang terikat pada bahan organik saja yang terikat lemah. Berdasarkan hasil penelitian tersebut maka peneliti merasa perlu melakukan penelitian tentang penentuan laju adsorpsi dan desorpsi paraquat pada tanah pertanian yang diambil dari Desa Oesao Kecamatan Kupang Timur sebagai salah satu kawasan agropolitan di Kabupaten Kupang.

\section{METODE PENELITIAN}

Penelitian ini dibagi menjadi 4 tahap yaitu preparasi sampel, evaluasi prosedur, penentuan laju adsorpsi senyawa paraquat pada tanah pertanian, dan studi desorpsi paraquat dengan menggunakan beberapa desorben. Tanah pertanian yang digunakan dalam penelitian ini berasal dari Desa Oesao, Kecamatan Kupang Timur.

\section{Bahan dan Alat}

Bahan yang digunakan dalam penelitian ini meliputi larutan gramoxon $276 \mathrm{~g} / \mathrm{L}$ (konsentrasi aplikasi paraquat), natrium ditionit, amonium klorida, natrium hidroksida (KGaA), akuades, air laut, kertas saring Whatman.

Peralatan gelas, neraca analitik (analytical balance brends cyo model GK 180), ball grinding mill, gelas polietilen, krus porselin, mechanical shaker $(K S$ 501D), ayakan berukuran 100 Mesh, Spektrofotometer UV-Vis (Spektronik 210 milton roy)

\section{Prosedur Penelitian \\ Preparasi Sampel}

Sampel tanah yang berasal dari Desa Oesao Kecamatan Kupang Timur ini berbentuk bongkahan. Sampel tanah yang diambil mempunyai kedalaman 0$30 \mathrm{~cm}$ dari permukaan tanah. Sampel ini dikeringkan di udara terbuka selama 14 hari. Setelah dikeringkan, sampel tanah yang berbentuk bongkahan digerus dengan krus porselin sampai menjadi serbuk yang halus. Serbuk tersebut diayak dengan ayakan berukuran 100 mesh sehingga dihasilkan serbuk tanah yang siap untuk digunakan.

\section{Evaluasi Prosedur}

\section{Penentuan panjang gelombang maksimum senyawa paraquat tereduksi}

Pembuatan larutan stok paraquat $276 \mathrm{mg} / \mathrm{L}$ dengan cara diambil $1 \mathrm{~mL}$ paraquat standar $276 \mathrm{~g} / \mathrm{L}$ dan diencerkan dengan akuades sampai $1000 \mathrm{~mL}$, dari larutan stok paraquat $276 \mathrm{mg} / \mathrm{L}$ ini diambil 3,42 $\mathrm{mL}$ kemudian diencerkan sampai $100 \mathrm{~mL}$ sehingga diperoleh konsentrasi $9,439 \mathrm{mg} / \mathrm{L}$. Selanjutnya paraquat dengan konsentrasi 9,439 mg/L diambil sebanyak $1 \mathrm{~mL}$ kemudian ditambahkan $1 \mathrm{~mL}$ natrium ditionit $1 \%$ (dalam pelarut $\mathrm{NaOH} \quad 0,1 \quad \mathrm{~N}$ ), dan diencerkan dengan akuades sampai 10 $\mathrm{mL}$. Larutan yang diperoleh pada langkah di atas dianalisis dengan menggunakan spektrofotometer UV-Vis dengan merekam absorbansinya pada $\lambda$ $400-800 \mathrm{~nm}$.

\section{Stabilitas senyawa paraquat tereduksi}

Diambil $1 \mathrm{~mL}$ larutan paraquat dengan konsentrasi 9,439 $\mathrm{mg} / \mathrm{L}$ dan ditambahkan $1 \mathrm{~mL}$ larutan ditionit $1 \%$ (dalam pelarut $\mathrm{NaOH}$ ) dan selanjutnya 
diencerkan dengan akuades sampai dengan $10 \mathrm{ml}$. Analisis dengan menggunakan spektrofotometer UV-Vis dilakukan terhadap larutan yang diperoleh pada langkah sebelumnya dengan merekam pola absorbansi senyawa-senyawa tersebut pada panjang gelombang maksimum untuk rentang waktu 0-150 menit.

\section{Sensitivitas metode analisis senyawa paraquat secara spektrofotometer}

Metode analisis untuk menentukan sensitivitas paraquat dilakukan dengan cara diambil $4 \mathrm{~mL}$ larutan stok paraquat $276 \mathrm{mg} / \mathrm{L}$, diencerkan sampai volume mencapai $100 \mathrm{~mL}$ sehingga mendapat larutan paraquat dengan konsentrasi 11,04 mg/L. Larutan yang diperoleh diambil $1 \mathrm{~mL}$ dan ditambahkan $1 \mathrm{~mL}$ natrium ditionit (pelarut $\mathrm{NaOH}$ ), diencerkan 25 kali sehingga diperoleh konsentrasi 0,4416 mg/L. Cara yang sama dibuat dengan mengambil 10, 14, 16, 18, 30, 40, dan $50 \mathrm{~mL}$ larutan stok paraquat $276 \mathrm{mg} / \mathrm{L}$ dan diencerkan sampai volume $100 \mathrm{~mL}$. Hasil yang diperoleh diencerkan 25 kali sehingga diperoleh larutan dengan konsentrasi 0,$4416 ; 1,104 ; 1,5456 ; 1,7664 ; 1,9872$; 3,$312 ; 4,416 ; 5,52 \mathrm{mg} / \mathrm{L}$. Seri larutan tersebut diukur absorbansinya pada serapan $\lambda$ maksimum dengan menggunakan spektrofotometer UV-Vis.

\section{Penentuan Laju Adsorpsi Senyawa Paraquat pada Tanah Pertanian \\ Penentuan laju adsorpsi senyawa paraquat pada tanah sebelum dijenuhkan}

Sebanyak 0,2 g tanah ditempatkan pada masing-masing 10 tabung gelas polietilen dan ditambahkan $10 \mathrm{~mL}$ larutan paraquat dengan konsentrasi $596,3 \mathrm{mg} / \mathrm{L}$. Masing-masing campuran diinteraksikan selama 5, 10, 20, 30, 60, $120,150,180,210$, dan 240 menit dan kemudian disaring. Filtrat dari campuran tersebut ditampung di gelas polietilen.
Diambil $1 \mathrm{~mL}$ dari masing-masing filtrat dan ditambahkan natrium ditionit $1 \%$ (dalam pelarut $\mathrm{NaOH} 0,1 \mathrm{~N}$ ) sebanyak 2,5 mL. Larutan tersebut kemudian diencerkan sampai volume mencapai 25 $\mathrm{mL}$ dan dianalisis dengan menggunakan spektrofotometer UV-Vis pada panjang gelombang maksimum.

\section{Penentuan laju adsorpsi senyawa paraquat pada tanah setelah dijenuhkan}

Sebanyak $10 \mathrm{~g}$ tanah ditambahkan $500 \mathrm{~mL}$ larutan paraquat dengan konsentrasi $828 \mathrm{mg} / \mathrm{L}$ dan dishaker selama 15 jam dan disaring. Hasil proses penyaringan tersebut ditempatkan pada wadah lain, kemudian ditambahkan $\mathrm{NH}_{4} \mathrm{Cl}$ jenuh sebanyak $250 \mathrm{~mL}$ dan dishaker kembali selama 2 jam. Campuran yang telah dishaker ini kemudian disaring dan dibilas dengan akuades sebanyak $250 \mathrm{~mL}$. Tanah dari hasil proses penyaringan tersebut dikeringkan di udara terbuka selama 96 jam.

Sebanyak $0,2 \mathrm{~g}$ tanah ditimbang dan ditempatkan pada masing-masing gelas polietilen sebanyak 10 buah. Tanah tersebut ditambahkan $10 \mathrm{~mL}$ larutan paraquat dengan konsentrasi 331,2 mg/L. Masing-masing campuran diinteraksikan selama $5,10,20,30,60,120,150,180$, 210, dan 240 menit dan kemudian disaring. Filtrat dari campuran tersebut ditampung di gelas polietilen. Diambil 1 $\mathrm{mL}$ dari masing-masing filtrat dan ditambahkan natrium ditionit $1 \%$ (dalam pelarut $\mathrm{NaOH} 0,1 \mathrm{~N}$ ) sebanyak 2,5 mL. Larutan tersebut kemudian diencerkan sampai volume mencapai $25 \mathrm{~mL}$ dan dianalisis dengan menggunakan spektrofotometer $\mathrm{UV}-\mathrm{V}$ is pada panjang gelombang maksimum.

\section{Studi Desorpsi Paraquat}

Sebanyak $10 \mathrm{~g}$ tanah ditimbang dan ditambahkan $10 \mathrm{~mL}$ larutan paraquat dengan konsentrasi $63480 \mathrm{mg} / \mathrm{L}$. 
Campuran tersebut diaduk hingga merata dan dibiarkan sampai mengering. Sebanyak 0,2 g dari masing-masing campuran tersebut ditempatkan pada 10 buah gelas polietilen. Campuran tersebut ditambahkan dengan akuades sebanyak $10 \mathrm{~mL}$ dan diinteraksikan selama 3, 6, 9, $12,15,30,60,90,120,180,240,360$, dan 480 menit dan kemudian disaring. Filtrat dari campuran tersebut ditampung di gelas polietilen. Diambil $1 \mathrm{~mL}$ dari masing-masing filtrat dan ditambahkan Natrium ditionit 1\% (dalam pelarut $\mathrm{NaOH}$ ) sebanyak 2,5 mL. Larutan tersebut diencerkan sampai volume mencapai $25 \mathrm{~mL}$ dan dianalisis dengan menggunakan spektrofotometer UV-Vis pada panjang gelombang maksimum. Metode yang sama dilakukan dalam proses desorpsi paraquat dengan menggunakan air laut dengan salinitas $29,2 \%$ dan $\mathrm{NH}_{4} \mathrm{Cl}$ jenuh sebagai desorben.
HASIL DAN PEMBAHASAN

Evaluasi Metode Analisis Paraquat Secara Spektrofotometri

\section{Panjang Gelombang Serapan Maksimum}

Paraquat merupakan salah satu golongan senyawa amonium kuartener. Senyawa ini dapat dianalisis secara langsung dengan menggunakan spektrofotometer UV-Vis karena kation paraquat memiliki kemampuan menyerap sinar UV sebagai akibat dari transisi elektronik $\pi$ pada ikatan rangkap terkonjugasi dalam gugus bipiridil. Panjang gelombang serapan senyawa paraquat pada $260 \mathrm{~nm}$ (Hassal, 1982).

Menurut Costenla dkk (1990) mereduksi paraquat dengan natrium ditionit dalam suasana basa, maka hasil reduksi paraquat ini akan menghasilkan warna biru pada larutan dengan serapan maksimum pada panjang gelombang di daerah sekitar $600 \mathrm{~nm}$. Pada penelitian ini pengukuran panjang gelombang serapan maksimum dilakukan pada panjang gelombang antara 450 sampai $800 \mathrm{~nm}$, seperti terlihat pada Gambar 3.

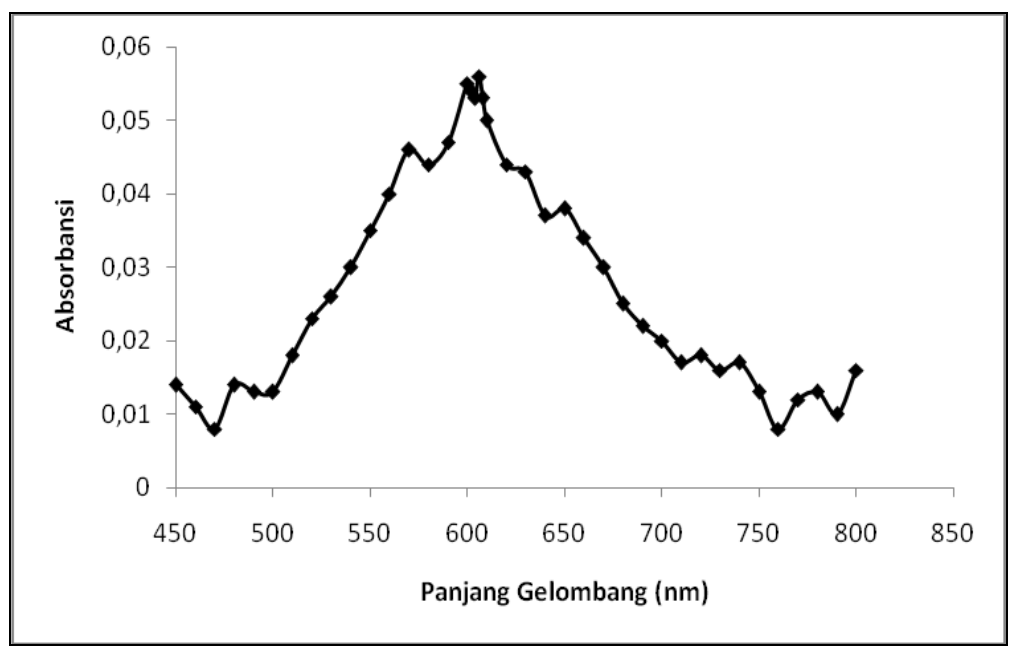

Gambar 3. Penentuan panjang gelombang maksimum hasil reduksi senyawa paraquat

Pada Gambar 3 terlihat bahwa senyawa paraquat yang direduksi menyerap radiasi pada panjang gelombang serapan maksimum $606 \mathrm{~nm}$. Menurut Asthon (1981) pada serapan panjang gelombang maksimum $606 \mathrm{~nm}$ diduga terjadi proses pembentukan ikatan konjugasi antara dua senyawa paraquat dengan perantara reduktor natrium ditionit. Pembentukan ikatan ini memperpanjang resonansi elektron sehingga menyebabkan penurunan energi 
internal. Oleh karena itu, energi yang dibutuhkan pada proses transisi ikatan konjugasi antara paraquat dengan perantara natrium ditionit menjadi lebih rendah.

\section{Stabilitas Senyawa Paraquat Tereduksi}

Waktu optimum pengukuran senyawa paraquat adalah pada saat senyawa tersebut berada dalam keadaan stabil yang dapat ditentukan dengan membuat kurva absorbansi paraquat terhadap waktu. Hasil pengamatan dapat dilihat pada Gambar 4.

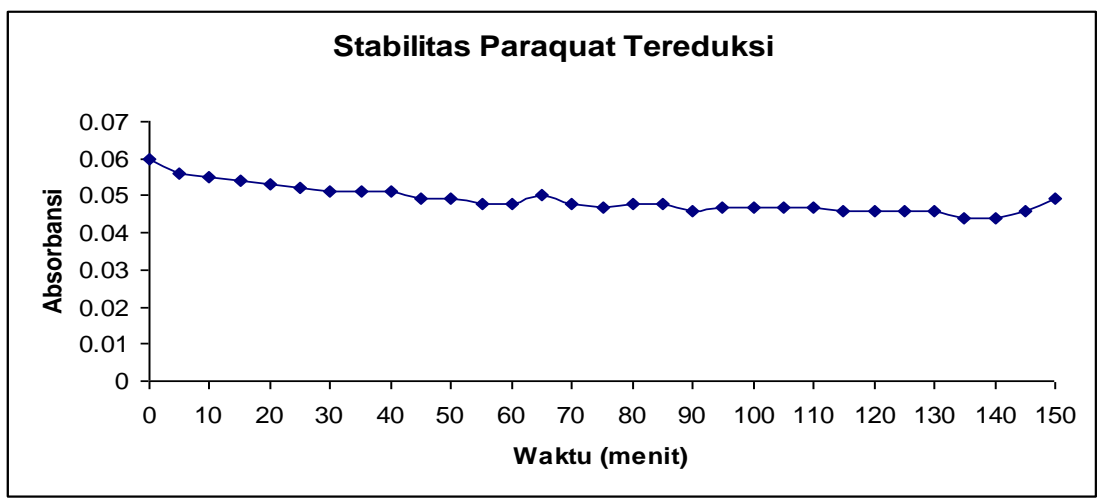

Gambar 4. Stabilitas paraquat tereduksi pada $\lambda_{\max } 606 \mathrm{~nm}$

Pada Gambar 4 terlihat bahwa senyawa paraquat relatif stabil pada waktu 0-150 menit, dimana pada rentang waktu tersebut pengukuran masih dapat dilakukan. Persamaan reaksi reduksi paraquat dapat dilihat pada Gambar 5.

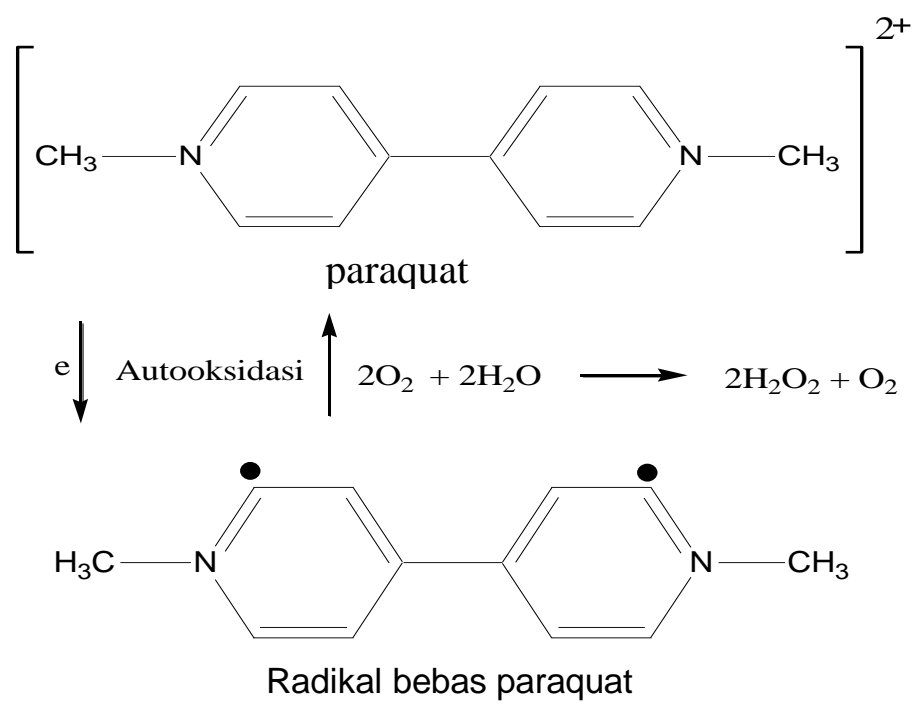

Gambar 5. Skema proses reduksi paraquat (Asthon,1981)

Pada persamaan reaksi reduksi paraquat akan menghasilkan senyawa radikal bebas paraquat yang memiliki sifat kurang stabil. Menurut Asthon (1981) radikal bebas paraquat akan mengalami proses autooksidasi sebagai akibat keberadaan oksigen dan air, dan membentuk kembali ion paraquat. Oleh karena itu, proses reduksi yang terjadi menghasilkan radikal bebas paraquat yang bersifat kurang stabil sehingga pengukuran terhadap analit dilakukan secepat mungkin yakni dalam rentang waktu 0-150 menit. 
Pada pengukuran absorbansi paraquat perlu diperhatikan stabilitas reduktor natrium ditionit $\left(\mathrm{Na}_{2} \mathrm{~S}_{2} \mathrm{O}_{4}\right)$, karena reduktor ini sangat menentukan besarnya nilai absorbansi. Reduktor natrium ditionit merupakan salah satu reagen yang memegang peranan penting dalam analisis kuantitatif paraquat dengan menggunakan metode spektrofotometer UV-Vis.

Metode pengukuran ini akan memperoleh hasil yang optimum apabila larutan natrium ditionit yang digunakan selalu berada dalam keadaan baru dimana penggunaannya tidak lebih dari 50 menit dan pengukuran terhadap absorbansi reduktor paraquat dilakukan secepat mungkin setelah penambahan larutan natrium ditionit.

\section{Sensitivitas dan Batas Deteksi Metode Analisis}

Sensitivitas metode analisis
senyawa paraquat spektrofotometer UV-Vis pada panjang gelombang maksimum $606 \mathrm{~nm}$, menggambarkan pengaruh variasi konsentrasi paraquat tereduksi terhadap absorbansinya. Sensitivitas dapat diperoleh dengan cara membuat kurva linier hubungan antara konsentrasi dan absorbansi. Berdasarkan kurva tersebut dapat ditentukan harga kemiringan (slope) dimana kemiringannya tersebut (slope) mewakili sensitivitas dari metode analisis. Kurva standar paraquat dapat dilihat pada Gambar 6.

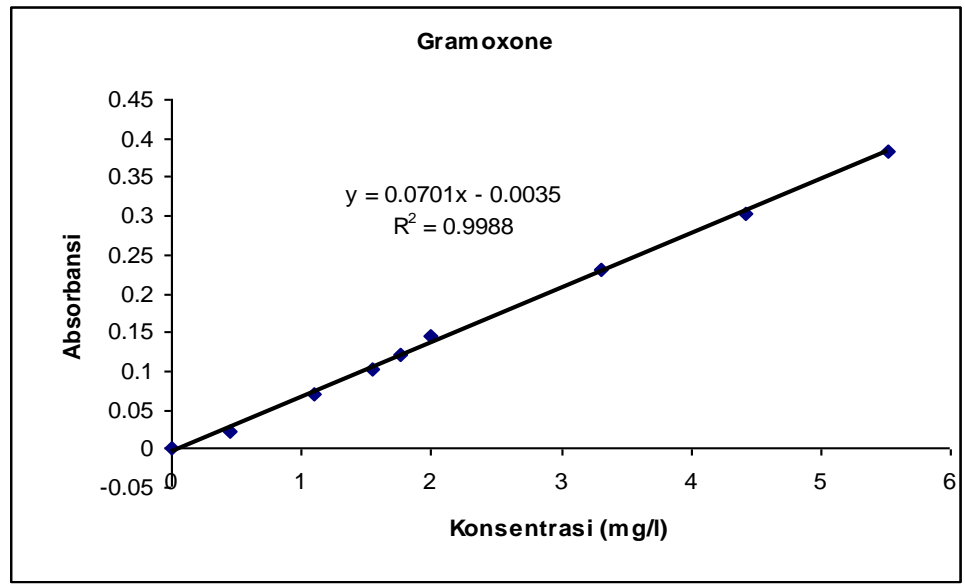

Gambar 6. Kurva standar paraquat

Berdasarkan hasil pengukuran kurva standar yang telah dibuat diperoleh persamaan regresi liniear $(y=b x+a)$, dengan slope (b) dan intersep (a) besarnya slope kurva kalibrasi ini menunjukkan nilai sensitivitas.Pada Gambar 6 terlihat bahwa nilai kemiringan (slope) untuk paraquat adalah 0,0701 dengan koefisien regresi $\boldsymbol{r}=0,9994$ sedangkan batas deteksi atau harga LOD untuk paraquat adalah 0,1997 mg/L. Harga LOD yang diperoleh menunjukkan bahwa konsentrasi tersebut masih dapat dideteksi oleh alat.

\section{Laju Adsorpsi}

Harga konstanta laju adsorpsi $\left(\mathrm{k}_{1}\right)$ dan konstanta kesetimbangan adsorpsi (K) dihitung dengan menggunakan persamaan kinetika Langmuir-Hinshelwood dengan modifikasi yang diusulkan oleh Santoso (2001) :

$$
\frac{\ln \left(C_{o} / C_{a}\right)}{C_{a}}=k_{1} \frac{t}{C_{a}}+K
$$

Hasil perhitungan yang diperoleh dapat dilihat pada Tabel 2. 
Tabel 2. Hasil perhitungan harga $\mathrm{k}_{1}$ dan $\mathrm{K}$ pada keadaan natural dan dijenuhkan

\begin{tabular}{|c|c|c|c|}
\hline \multicolumn{4}{|c|}{ Paraquat } \\
\hline \multicolumn{2}{|c|}{ Natural } & \multicolumn{2}{c|}{ Dijenuhkan } \\
\hline $\mathrm{k}_{1}\left(\mathrm{~m}^{-1}\right)$ & $\mathrm{K}\left(\mathrm{M}^{-1}\right)$ & $\mathrm{k}_{1}\left(\mathrm{~m}^{-1}\right)$ & $\mathrm{K}\left(\mathrm{M}^{-1}\right)$ \\
\hline 0,011 & 11670 & 0,003 & 1030 \\
\hline
\end{tabular}

Hasil yang diperoleh pada Tabel 2 menunjukkan adanya kecenderungan penurunan harga konstanta laju $\left(\mathrm{k}_{1}\right)$ dan konstanta kesetimbangan (K) apabila adsorben tanah tersebut dijenuhkan terlebih dahulu dengan senyawa paraquat, maka dapat dikatakan bahwa harga $\mathrm{k}_{1}$ dan harga $\mathrm{K}$ pada keadaan natural lebih besar dari harga $\mathrm{k}_{1}$ dan harga $\mathrm{K}$ pada keadaan dijenuhkan. Hal ini disebabkan untuk tanah yang telah dijenuhkan paraquat telah ditambahkan amonium klorida jenuh yang berfungsi untuk mendesorpsi paraquat. Amonium klorida yang digunakan ini didesorpsi kembali dengan akuades yang bertujuan untuk melepaskan ion amonium tersebut dari adsorben tanah. Proses pelepasan ion amonium dari situs aktif tanah diduga tidak maksimal, hal ini mengindikasikan bahwa masih ada ion amonium yang masih terikat pada permukaan situs aktif tanah.

Keberadaan ion amonium ini menyebabkan terjadinya perubahan karakter dari situs aktif permukaan adsorben tanah. Ion amonium yang terikat pada situs aktif permukaan adsorben tanah menyebabkan meningkatnya sifat elektrostatik dari permukaan padatan tanah. Peningkatan sifat elektrostatik dari permukaan adsorben tanah ini menyebabkan paraquat yang ditambahkan setelah jenuh akan mengalami proses kompetisi dengan ion amonium untuk terikat pada situs negatif dari tanah. Oleh karena itu, secara tidak langsung dapat terlihat dengan jelas bahwa bahwa laju adsorpsi pada keadaan natural berlangsung lebih cepat, sedangkan laju adsorpsi dijenuhkan berlangsung lambat.

\section{Desorpsi Senyawa Paraquat}

Penelitian ini dilakukan untuk memperoleh informasi mengenai lamanya waktu yang diperlukan pada proses desorpsi paraquat pada tanah Oesao dan untuk mendapatkan informasi tentang kemampuan dari beberapa jenis desorben yaitu akuades, air laut dengan salinitas $29,2 \%$ dan larutan amonium klorida jenuh dalam mendesorpsi paraquat. Sehingga dapat diketahui jenis ikatan yang berperan dalam proses adsorpsi paraquat pada tanah. Hasil penelitian desorpsi paraquat dengan variasi waktu desorpsinya dapat dilihat pada Gambar 7.

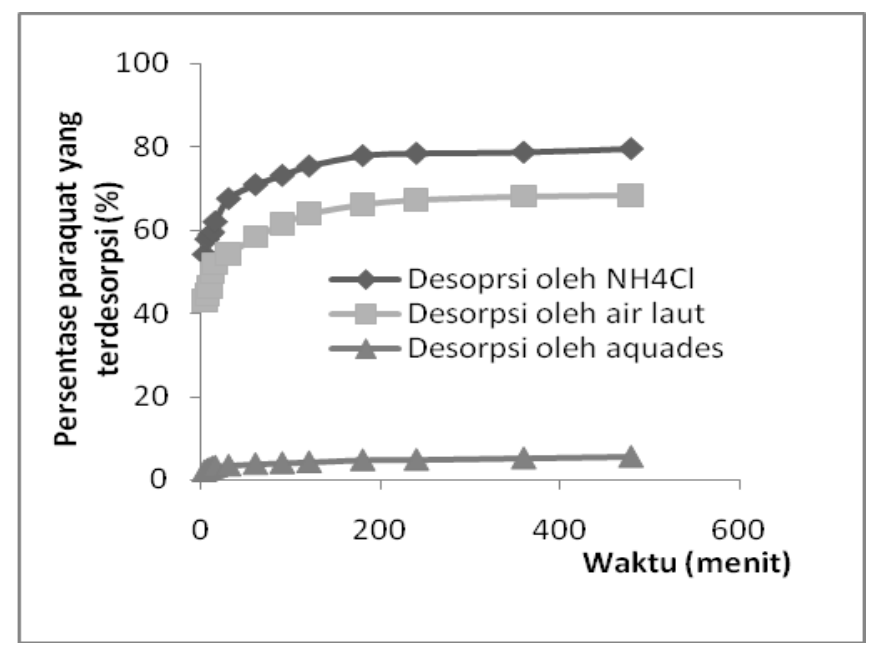

Gambar 7. Desorpsi paraquat pada tanah Oesao dengan beberapa desorben 
Apabila dilihat hasil pada Gambar 7. terlihat bahwa jumlah paraquat yang didesorpsi sangat cepat. Proses desorpsi paraquat cenderung mencapai kestabilan pada $\mathrm{t}=180$ menit, dimana pada waktu tersebut paraquat yang terdesorpsi oleh air laut dan $\mathrm{NH}_{4} \mathrm{Cl}$ telah mencapai keadaan maksimal, dan pada akuades cenderung stabil. Jumlah persentase paraquat yang didesorpsi oleh $\mathrm{NH}_{4} \mathrm{Cl}$ jenuh paling besar dari air laut dan akuades, maka dapat dikatakan $\mathrm{NH}_{4} \mathrm{Cl}$ jenuh paling baik dalam mendesorpsi paraquat.

Proses desorpsi paraquat dengan desorben akuades $\left(\mathrm{H}_{2} \mathrm{O}\right)$ mengindikasikan adanya keterlibatan reaksi asam basa. Pada proses desorpsi ini, tanah oesao yang tergolong tanah basa $(\mathrm{pH} 7,61)$, paraquat yang terikat bersifat sebagai asam (donor proton) sedangkan gugus $\mathrm{Si}-\mathrm{O}-\mathrm{Al}$ dalam aluminosilikat tanah berfungsi sebagai basa (akseptor proton). Proses yang terjadi, ion paraquat (1,1-dimetil-4,4bipiridilium) yang terikat pada gugus $\mathrm{Si}$ $\mathrm{O}-\mathrm{Al}$ dalam aluminosilikat tanah digantikan oleh ion $\mathrm{H}^{+}$dari $\mathrm{H}_{2} \mathrm{O}$. Namun demikian, ion $\mathrm{H}^{+}$dari $\mathrm{H}_{2} \mathrm{O}$ tidak mampu untuk menggantikan ion paraquat yang terikat kuat pada gugus Si-O-Al dalam aluminosilikat tanah. Hal ini disebabkan karena ion paraquat memiliki ukuran yang lebih besar dari ion $\mathrm{H}^{+}$, sehingga kemampuan $\mathrm{H}_{2} \mathrm{O}$ untuk mendesorpsi sangat sedikit dan cenderung stabil.

Proses desorpsi paraquat oleh desorben air laut dengan salinitas 29,2\% dan $\mathrm{NH}_{4} \mathrm{Cl}$ jenuh menunjukkan keterlibatan proses pertukaran kation antara ion $\mathrm{NH}_{4}^{+}$dan $\mathrm{Na}^{+}$dengan ion paraquat (1,1-dimetil-4,4-bipiridilium). Hasil yang diperoleh terlihat bahwa desorpsi oleh $\mathrm{NH}_{4} \mathrm{Cl}$ jenuh dan air laut tidak jauh berbeda, namun $\mathrm{NH}_{4} \mathrm{Cl}$ jenuh paling banyak mendesorpsi. Menurut Tan (1991) garam-garam yang biasanya digunakan untuk pertukaran kation yakni $\mathrm{Ba}^{2+}, \mathrm{Sr}^{2+}, \mathrm{Na}^{+}$, dan $\mathrm{NH}_{4}^{+}$, pertukaran kation yang menggunakan ion $\mathrm{NH}_{4}{ }^{+}$ sering menghasilkan nilai pertukaran yang lebih tinggi daripada ion-ion lainnya yang digunakan. Oleh karena itu, $\mathrm{NH}_{4}{ }^{+}$mempunyai daya desorpsi yang lebih besar daripada air laut yang mengandung garam-garam seperti klorida, natrium, sulfat, magnesium, kalsium, dan potasium.

Seperti yang terlihat pada gambar 7, walaupun desorben-desorben tersebut memiliki kemampuan untuk mendesorpsi paraquat yang terikat pada tanah, tetapi ketiga desorben tersebut tidak mampu mendesorpsi semua paraquat yang berada di dalam tanah. Hal ini disebabkan karena terdapat dua jenis ikatan yaitu ikatan antara kation paraquat yang terikat pada permukaan luar tanah, dan kation paraquat yang terperangkap dalam saluran tanah.

Pada proses adsorpsi senyawa paraquat pada tanah Oesao, dimana pada tanah ini terdapat mineral montmorilonit dan bahan organik yang situs-situs aktifnya sebagian besar bermuatan negatif maka hanya kation 1,1-dimetil4,4-bipiridilium yang teradsorpsi pada permukaan luar dan yang terikat pada bahan organik saja yang terikat lemah. Ikatan yang lemah ini mudah dilepaskan melalui mekanisme pertukaran kation dengan adanya kation $\mathrm{NH}_{4}^{+}$dan $\mathrm{Na}^{+}$. Untuk kation 1,1-dimetil-4,4-bipiridilium yang teradsorpsi pada saluran tanah, proses desorpsi melalui pertukaran kation tidak dapat terjadi karena muatan-muatan positif dari ion 1,1-dimetil-4,4bipiridilium lebih besar dari kation $\mathrm{NH}_{4}{ }^{+}$ dan $\mathrm{Na}^{+}$. Gejala ini menunjukkan bahwa kecilnya kemungkinan ion $\mathrm{Na}^{+}$dan $\mathrm{NH}_{4}{ }^{+}$ dapat mendorong atau menggantikan kation 1,1-dimetil-4,4-bipiridilium dari dalam saluran yang terdapat pada mineral tanah. 


\section{KESIMPULAN DAN SARAN \\ Kesimpulan}

Berdasarkan hasil penelitian maka dapat disimpulkan:

1. Senyawa paraquat yang direduksi menyerap radiasi pada $\lambda$ maksimum $606 \mathrm{~nm}$ dan stabilitas pengukuran relatif pada rentang waktu $0-150$ menit.

2. Konstanta laju adsorpsi senyawa paraquat pada Tanah Oesao keadaan natural lebih besar dari pada keadaan dijenuhkan yakni pada keadaan natural harga $\mathrm{k}_{1}$ 0,011 menit ${ }^{-1}$ dan harga $\mathrm{k}_{1}$ keadaan dijenuhkan 0,003 menit $^{-1}$.

3. Pola desorpsi senyawa paraquat dengan menggunakan desorben amonium klorida, air laut dengan salinitas 29,2\%, dan akuades menunjukkan bahwa desorben amonium klorida mendesorpsi senyawa paraquat paling baik dibanding kedua desorben lain.

\section{Saran}

Perlu dilakukan penelitian lebih lanjut mengenai adanya keterlibatan senyawa-senyawa aditif dalam gramoxon sebagai konsentrasi aplikasi dari paraquat pada penentuan laju adsorpsi $\left(\mathrm{k}_{1}\right)$ senyawa paraquat pada tanah.

\section{DAFTAR PUSTAKA}

Asthon, F. M., 1981, Mode of Action of Herbicides, $2^{\text {nd }}$ edition. A WileyInterscience Publication, New York.
Bangun, P. dan Pane, H., 1984, Pengantar Penggunaan Herbisida Pada Tanaman Pangan, Buletin Teknik No.7, Pusat Penelitian dan Pengembangan Tanaman Pangan, Bogor.

Constenla, M. A., 1990, Paraquat Behavior in Costa Rica Soils and Residues in Coffe, Journal Agriculture Food Chemistry, Vol 38.

de Rozari, P. 2001, Studi AdsorpsiDesorpsi Paraquat pada Tanah Kalimantan dan Toksisitasnya terhadap Chlorela sp, Thesis Universitas Gadjah Mada Yogyakarta.

Hassal, K.A., 1982, The Biochemistry and Uses of Pesticides, $2^{\text {nd }}$ Edition. Macmillan Press, New York.

Kopytko, M., G. Chalela dan F. Zauscher, 2002, Biodegradation of Two Commercial Herbicides (Gramoxone and matancha) by Bacteria Pseudomonas Putida. Electronic Journal of Biotechnology, 5 : 182-192.

Sastroutomo, S.S., 1992, Pestisida : Dasar-Dasar dan Dampak Penggunannya, PT. Gramedia Pustaka Utama, Jakarta.

Sudarmo, S., 1988, Pestisida Tanaman, Kanisius, Yogyakarta. 